\title{
Review: New considerations to refine breeding objectives of dairy cows for increasing robustness and sustainability of grass-based milk production systems
}

\author{
J. R. Roche ${ }^{1,2 a \dagger}$, D. P. Berry ${ }^{3}$, L. Delaby ${ }^{4}$, P. G. Dillon ${ }^{3}$, B. Horan $^{3}$, K. A. Macdonald ${ }^{1}$ \\ and M. Neal ${ }^{1}$ \\ ${ }^{1}$ DairyNZ, Hamilton 3240, New Zealand; ${ }^{2}$ School of Biological Sciences, University of Auckland, Private Bag 92019, Auckland 1142, New Zealand; ${ }^{3}$ Teagasc \\ Moorepark, Fermoy, Co. Cork P61 C996, Ireland; ${ }^{4}$ INRA, Agrocampus Ouest, UMR Physiologie, Environnement et Génétique pour l'Animal et les Systèmes d'Elevage, \\ 16 Le Clos, F-35590, Saint Gilles, France
}

(Received 4 February 2018; Accepted 7 September 2018; First published online 13 November 2018)

\begin{abstract}
Although food from grazed animals is increasingly sought by consumers because of perceived animal welfare advantages, grazing systems provide the farmer and the animal with unique challenges. The system is dependent almost daily on the climate for feed supply, with the importation of large amounts of feed from off farm, and associated labour and mechanisation costs, sometimes reducing economic viability. Furthermore, the cow may have to walk long distances and be able to harvest feed efficiently in a highly competitive environment because of the need for high levels of pasture utilisation. She must, also, be: (1) highly fertile, with a requirement for pregnancy within $~ 80$ days post-calving; (2) 'easy care', because of the need for the management of large herds with limited labour; (3) able to walk long distances; and (4) robust to changes in feed supply and quality, so that short-term nutritional insults do not unduly influence her production and reproduction cycles. These are very different and are in addition to demands placed on cows in housed systems offered pre-made mixed rations. Furthermore, additional demands in environmental sustainability and animal welfare, in conjunction with the need for greater system-level biological efficiency (i.e. 'sustainable intensification'), will add to the 'robustness' requirements of cows in the future. Increasingly, there is evidence that certain genotypes of cows perform better or worse in grazing systems, indicating a genotype $x$ environment interaction. This has led to the development of tailored breeding objectives within countries for important heritable traits to maximise the profitability and sustainability of their production system. To date, these breeding objectives have focussed on the more easily measured traits and those of highest relative economic importance. In the future, there will be greater emphasis on more difficult to measure traits that are important to the quality of life of the animal in each production system and to reduce the system's environmental footprint.
\end{abstract}

Keywords: pasture-based, dairy production systems, robustness, breeding objectives, profitability

\section{Implications}

The existence of genotype $\times$ environment interactions means that the extremes of dairy production systems will benefit from individualised system-level breeding objectives. For systems to remain robust to economic and consumer-led drivers, future grazing systems will require cows that have a lower environmental footprint and thrive in an environment that has periodic interruptions to feed supply, while being 'easy care' and efficient converters of foraged feed into milk.

\footnotetext{
a John Roche was the invited contributor to the 2018 International Symposium on Nutrition of Herbivores. Other authors are listed alphabetically.

† E-mail: john.roche@dairynz.co.nz
}

\section{Introduction}

Robustness, in any system, reflects the ability of the system to absorb and withstand change and rebound from challenges to achieve the same or greater performance (Roche and Horan, 2013). This is true for businesses, animals and the people who manage them. Historically, the aim of agricultural production systems was to ensure adequate amounts of high quality foodstuffs for people. However, with the exponential increase in food production since the 1960s and the associated improvement in the nutrition of most of the world's population, the focus has shifted from a need for food, to a desire for a more multi-faceted approach to food production. Future global food production systems, therefore, face a four-fold challenge: 
i) meet the rapidly changing demand for food within a resource-constrained environment (e.g. including as a result of climate change);

ii) do so in an environmentally and socially sustainable manner for both consumers and producers;

iii) ensure that the products meet the highest standards of safety and nutritional value for increasingly discerning consumers; and

iv) ensure sufficient financial return to producers.

Producing more food from the same land area, while reducing environmental impacts and addressing animal welfare concerns, will require what has been referred to as the 'sustainable intensification' (Pretty, 1997; Pretty and Bharucha, 2014) or the 'ecological intensification' (Bommarco et al., 2013; Hochman et al., 2013; Tittonell, 2014) of agricultural production. The challenge, therefore, is to improve the efficiency with which natural resources are used, so that the amount of food produced from existing farmland can be increased while, at the same time, reducing environmental degradation, maintaining or improving the animal's quality of life and providing a sustainable economic return to the farmer. Although sustainable intensification in all livestock-based production systems will require innovative blueprints for production, in grazing production systems, it will fundamentally depend on increased pasture production and quality and improved pasture utilisation. This has implications for feed allowance per animal and the associated environmental footprint. In the following passages, we will provide insight into the peculiarities of intensive grazing systems that expect a large proportion of the cow's diet to be selfharvested pasture, how genetics influences the cow's ability to function and survive in these systems and how genetic selection priorities have evolved to accommodate genotype $\times$ environment $(G \times E)$ interactions, what a robust grazing systems looks like and how it affects farm profitability and environmental sustainability, and, finally, the most important traits for cow robustness.

\section{Peculiarities of a grazing system}

Among dairy production systems, grazing systems are peculiar in that (1) they are designed to work within the immutable and immediate natural forces of climate (i.e. weather); (2) the majority of feed management is undertaken autonomously by the cow, with minimal use of mechanisation; and (3) the base forage in grazing systems is fresh and, therefore, perishable; if it is not used, it decays in the paddock and is wasted. As such, grazing systems differ from housed systems in that in the latter, the farmer must manage stocks of feed and apportion them relative to cow demand, whilst, in the former, the farmer is required to manage the flux between cow demand and an unpredictable supply, including supplementary feeds in the daily allocation when pasture growth is insufficient to meet cow demand, and conserving pasture as hay or silage in times of surplus growth. As a result, grazing systems tend to be situated primarily in the centre of the temperate climatic zones (between latitudes 35 and $50^{\circ}$ North and South), where air and soil temperature and precipitation follow relatively repeatable within-year sinusoidal profiles (Roche et al., $2009 \mathrm{~b}$ and 2009c). In these latitudes, the climate facilitates the production of relatively large volumes (12 to $20 t \mathrm{DM}$ ) of high quality ( $>70 \%$ DM digestibility) perennial and annual grazeable forages (i.e. pastures) that re-grow following defoliation (Roche et al., 2009c).

The cost of producing $1 \mathrm{~kg}$ of milk or $1 \mathrm{~kg}$ of fat and protein has been identified as the key determinant of operating profitability in grazing production systems, with milk production/cow or per ha explaining less than half as much of the variability in operating profit/ha (Ramsbottom et al., 2015). In an analysis of dairy production systems globally, Dillon et al. (2005) reported a strong quadratic relationship between the quantity of grazed pasture in the diet and the cost of producing $1 \mathrm{~kg}$ of milk: operating expenses $/ \mathrm{kg}$ milk declined with increased reliance on grazed pasture. This relationship was particularly steep in intensive grazing systems (i.e. more than $50 \%$ of the cow's diet as grazed pasture). Therefore, to minimise expenditure, more than $80 \%$ of the pasture is harvested directly by the cow (Dillon et al., 2005), reducing the need for mechanisation and associated costs.

A further peculiarity of grazing systems to consider when comparing with housed systems where cows are fed mixed rations is the requirement to use forage quickly. In either system, if the level of concentrate fed is increased, the base forage content of the diet is reduced. In a housed system, however, the base forage is already preserved in a silo, bunker or bale and, if not used at that point in time, it can be used at a later date without a material loss in quality. In comparison, in a grazing system, the forage is fresh; it is perishable and cannot be stored long in situ for later use. Therefore, if a supplement is substituted for pasture, the feed is wasted and the associated costs expended without financial return. In fact, when pasture is not consumed, but left in the paddock, the digestibility and metabolisable energy of pasture subsequently presented to the cow is less (Stakelum and Dillon, 1991) and milk production from pasture declines. The recognition of a 'use it or lose it' principle for the base forage is important in farm system-level nutritional management in a pasture-based system (Roche, 2017).

\section{Grazing systems - the coordination of feed supply and demand}

In milk or meat production from pasture, the dual aims of successful grazing systems are to:

i) maximise the utilisation of pasture grown/ha; and

ii) have the cow consume as much of her diet from grazed forages, with minimal use of labour, mechanisation and capital infrastructure for feeding. 


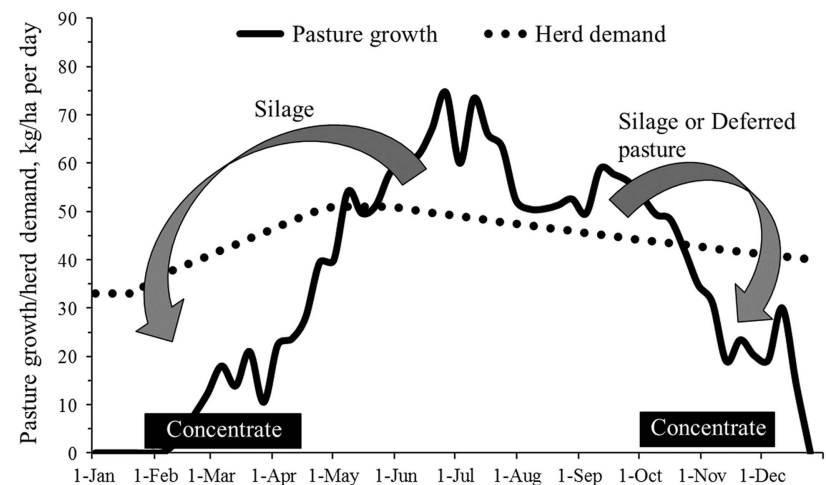

Figure 1 Schematic representative of the feed-flow in cattle grazing systems in the northern hemisphere. In the southern hemisphere, this feed flow is offset by 6 months (i.e. 1 January $=1$ June).

With intensive grazing systems being traditionally focussed in temperate climatic zones, these aims are complicated by the seasonal nature of pasture supply (i.e. zero to low pasture growth in winter, very high growth rates in spring, variable growth and feed quality during summer and moderate, but declining growth rates in autumn; Figure 1; Roche et al., 2009b). Although not as extreme in shape, the temporal profile of cow dry matter intake (DMI) is similar to that of temperate pasture production. Taking advantage of this, and the fact that pasture can be stored for relatively long periods in situ during autumn and winter (up to 100 days), without much loss of feed quality, seasonal production systems have been developed to ensure lactating cows are well fed on:

- stored pasture, with or without concentrates, during early lactation;

- pasture alone during mid-lactation;

- pasture and pasture/cereal silage, with or without grains or co-product feeds (i.e. concentrates), during late lactation; and

- pasture, forage crops or pasture/cereal silage during the non-lactating period.

Simply, if there is sufficient pasture available, the cows are fed on pasture alone. If there is insufficient pasture to meet the cows' nutrient requirements, silages, silages and concentrate feeds or root crops will be offered. If pasture growth exceeds herd requirements, surplus pasture is conserved as hay or silage in late spring and summer or 'deferred' for later grazing in the autumn (Figure 1).

To facilitate the synchrony between feed supply and demand, cows need to calve during a short 8- to 12-week window before peak pasture growth (i.e. seasonal calving system; Figure 2; Berry et al., 2012). This ensures that peak herd demand coincides with peak pasture supply and that the period of minimum feed demand of the herd (i.e. when cows are not lactating) coincides with the period of lowest pasture production (i.e. during winter). However, it also means that the period of breeding cows is equally short, and requires cows to establish a successful pregnancy within $\sim 80$ days of calving (Berry et al., 2012; Roche et al., 2017b).

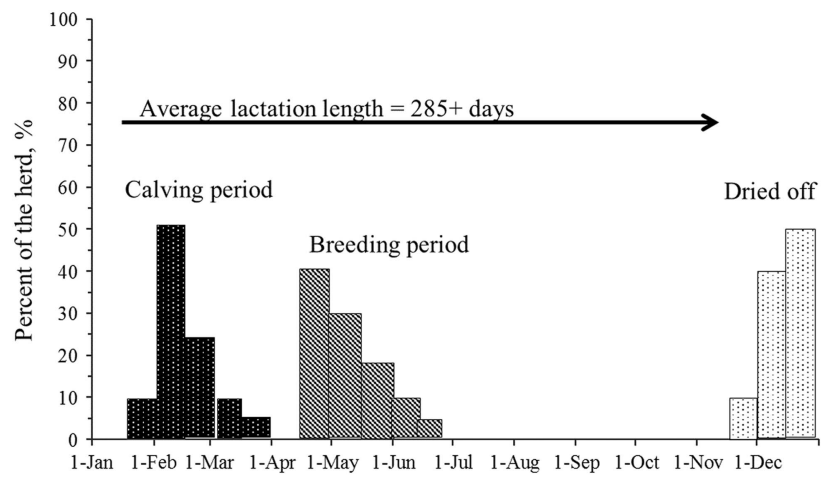

Figure 2 Timing of major animal-related events in a pasture-based, seasonal dairying calendar in the northern hemisphere in cattle. In the southern hemisphere, the calendar is offset by 6 months (i.e. 1 January $=1$ June).

A further consideration in comparing grazing systems with housed, mixed-ration systems is that:

- cost of the base milk produced from forage in grazing systems is very low and marginal milk from imported feeds is more expensive (Ramsbottom et al., 2015; Macdonald et al., 2017);

- cost of base milk produced from forage in mixed-ration systems is very high and marginal milk from concentrate feeds is much less expensive.

This difference has led to confusion about the appropriateness of imported (i.e. non-pasture feeds) feed in grazing systems. In housed, mixed-ration systems, where machinery and labour are already in place, additional milk from feed merely requires the replacement of an inferior feed ingredient with a superior feed ingredient, within the requirements of acceptable ration balancing and as long as the total ration cost fits within the strategic 'milk to feed price ratio' for the business. In fact, in this scenario, the additional milk helps to reduce the fixed costs, the majority of which have already been incurred.

The same logic has been expressed for grazing systems; however, the system-level ramifications are materially different. First, in grazing systems, imported feeds must be used in situations of genuine feed deficit; therefore, it is necessary to increase stocking rate (i.e. cows/ha) to achieve large responses to imported feeds (Macdonald et al., 2017). However, $50 \%$ to $60 \%$ of a grazing farm's costs are associated with each cow (i.e. 'fixed cost'; Macdonald et al., 2011). Therefore, the use of imported feeds to increase milk production/ha increases fixed costs/ha and the marginal cost of this milk is often greater than the cost of base milk and, sometimes, greater than the milk price (Ramsbottom et al., 2015; Macdonald et al., 2017). Macdonald et al. (2017) reported that filling a feed deficit with imported feed or introducing high yielding forage crops, such as maize, would result in a reduction in profitability/ha. In fact, Macdonald et al. (2017) estimated that it was prudent only to fill $90 \%$ of the feed deficit, except in situations of very high milk prices or very low feed prices. On average, for every $€ 1$ spent on feed 

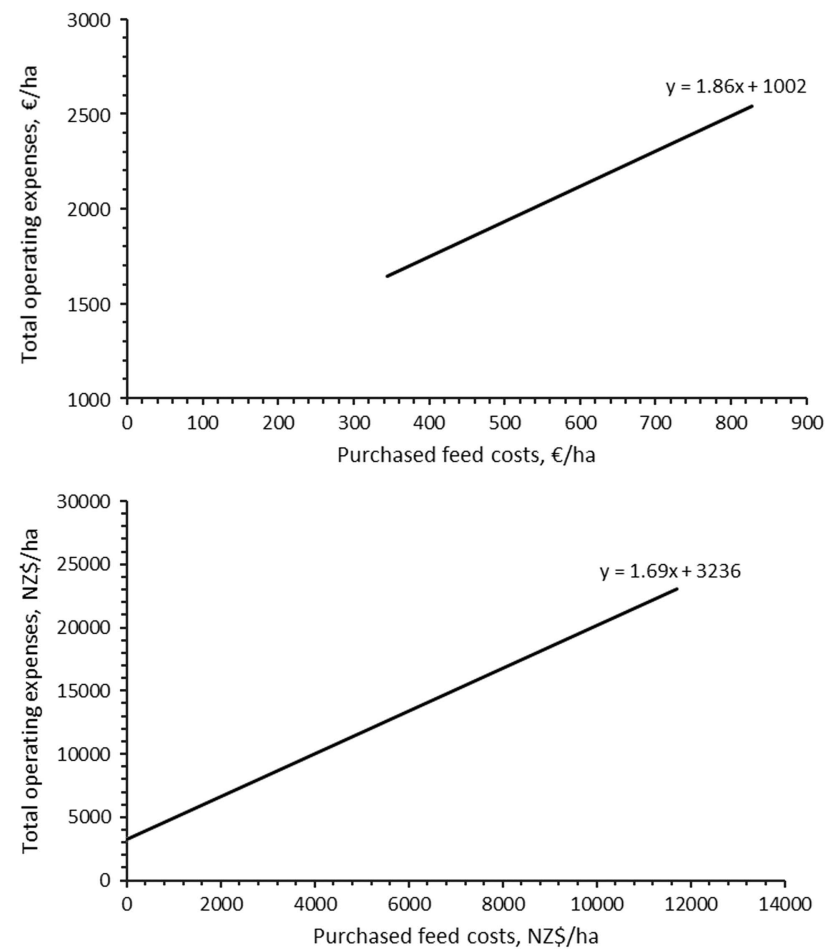

Figure 3 Association between feed costs/ha and total operating expenses in Ireland (top graph: 2759 dairy farm-years; Ramsbottom et al., 2015) and New Zealand (bottom graph: 8331 dairy farm-years; DairyBase data) in cattle. For Ireland, total operating expenses increase by $€ 1.69$ for every $€ 1$ spent on purchased feed, whereas in New Zealand total operating expenses increase by $€ 1.86$.

in grazing systems, total costs increase by $€ 1.60$ to $€ 2.00$ (DairyCo, 2013; Ramsbottom et al., 2015; New Zealand DairyBase, unpublished data; Figure 3).

Although grazing systems can vary from the archetypical grazing system portrayed in Figures 1 and 2 (Roche et al., 2017b) due to climatic challenges (i.e. less conducive to longer pasture growing seasons), variations in milk price and the price and availability of non-pasture feeds, and differences in farmer goals and aspirations, the system-level challenges and, in particular, the challenges for the dairy cow are similar across grazing systems, although, admittedly, the scale of the challenge can vary from farm to farm and location to location.

\section{What is a robust grazing dairy system?}

While it has always been difficult to predict international commodity prices or foresee production risks, the reduction in product stores and government intervention policies in many countries and increasing wealth in countries previously regarded as 'developing' has led to price volatility, arguably, not witnessed previously (Roche and Horan, 2013). Future milk production will, therefore, be set against a background of increased farm business uncertainty. Furthermore, the lack of certainty around mean and extreme temperatures, rainfall and the risk of severe weather events with future climate change scenarios could also have considerable impact on future dairy systems. As a result, future farm systems must be sufficiently robust to respond positively and rapidly to change.

Robust businesses are designed to utilise their competitive and comparative advantages. For grazing systems, this involves:

- maximising the utilisation of grazed pasture, an inexpensive, highly balanced feed that was, largely, paid for in the purchase or lease cost of the land (i.e. competitive advantage);

- ensuring that the management systems equate to good custodians of the environment and the animals under our care, thereby furthering the consumer's desire for products derived from grazing systems (i.e. comparative advantage).

For dairy systems, Roche and Horan (2013) went further, defining robust dairy systems as those that (1) provide a reasonable rate of return on equity invested; (2) are environmentally sustainable and animal welfare compliant; (3) allow for an enjoyable and rewarding lifestyle; and (4) allow opportunities for training and personal development.

In summary, robust grazing dairy systems need to be profitable and biologically, socially and environmentally acceptable. The cow has a significant influence on these parameters, affecting business profitability, the farm's environmental footprint, whether her own quality of life is acceptable in the defined system, and whether she is easy to manage (i.e. 'easy care') or requires significant time investment.

\section{Profitability and biological robustness}

For a farming business to be robust, it must be consistently profitable, even in the face of challenges. Profitability is defined as the difference between revenue and costs (i.e. operating profit) relative to the value of the asset (i.e. return on asset) and relative to the ability of the business to pay debt (i.e. solvency) or reward investment (i.e. return on equity invested). Although all are unique business metrics, they are, ultimately, a reflection of operating profit/ha, which is explained, in large part, by the unit cost of production $(\mathrm{c} / \mathrm{kg}$ of milk or c/kg fat and protein; Ramsbottom et al., 2015).

In grazing systems, operating expenses $/ \mathrm{kg}$ of milk or per kilogram of milk fat and protein produced are strongly related to pasture utilisation/ha (Ramsbottom et al., 2015) and the proportion of the cow's diet that is grazed pasture (Dillon et al., 2005). Therefore, robust grazing dairy farm systems are designed to utilise a large proportion of the pasture grown/ha, but also require that pasture constitutes a high proportion of the cow's diet. These suggestions for robustness were supported by the recent analysis of farm systems experiments by Macdonald et al. (2017); they reported a decline in profitability when non-pasture feeds constituting $>30 \%$ of the cow's total diet were used either to increase the stocking rate (i.e. expansion) or fill feed deficits in an already high stocking rate system (i.e. intensification). 
The archetypical grazing system was associated with selfcontained farms that nourished cows with fresh pasture when growth was plentiful and with conserved pasture (i.e. silage or hay) when demand exceeded growth rate. These systems were common in temperate climatic zones until the 1970s and typical for New Zealand until the 2000s. However, longer periods of low rainfall in some temperate zones (e.g. Australia), larger cows, increased stocking rates, improved genetic merit for milk production, availability of seemingly inexpensive grains and co-product feeds and social awareness around animal welfare (real and perceived) have all led to the increased importation of feeds into grazing systems as a way of improving 'biological robustness'. For example, genetic improvements for milk production resulted in cows mobilising greater amounts of body condition $(\mathrm{BC})$ in early lactation and a resistance to replenishing $B C$ stores while lactating (Roche et al., 2006a; Macdonald et al., 2008b). Although imported feeds did little to arrest BC loss in early lactation (Roche et al., 2006a, 2009a; Roche, 2007), they facilitated $B C$ replenishment during late lactation and during the non-lactating period. The importation of feed or the growing of high yielding crops to be harvested and offered to cows as a supplementary feed were, therefore, viewed as a component of robustness and biological sustainability (i.e. ensuring cows were returned to the same $B C$ before the next calving event). However, they were also used to increase stocking rate, increasing, further, the need for imported feeds (Macdonald et al., 2017) and increasing the farm's environmental footprint (Huebsch et al., 2013; Roche et al., 2016a).

Although component- and system-level studies have resulted in a greater understanding of marginal milk production responses to supplementary feeds, the literature does not facilitate the investigation of system-level and profitability-related effects of increasing levels of supplementation from zero input. Therefore, it is not possible to determine an optimum level of supplementation to accommodate the seemingly conflicting economic and biological requirements of robustness. However, Ramsbottom et al. (2015) reported a linear decline in profitability when feed importation exceeded $500 \mathrm{~kg} \mathrm{DM} / \mathrm{cow}$. This amount is approximately equivalent to $3.5 \mathrm{~kg}$ DM feed for 150 days. A greater feed allowance/cow would require an increase in stocking rate to ensure pasture utilisation is maintained (Roche et al., 2017b), with an increase in fixed costs/ha associated with the increase in cows milked (Macdonald et al., 2011 and 2017), and a likely increase in the farm's environmental footprint (Roche et al., 2016b). Macdonald et al. (2017) questioned the economic viability of this strategy, with the cost of the marginal milk produced considerably greater than the milk price except when milk price was exceptionally high or feed prices were exceptionally low. In support, Ramsbottom et al. (2015) reported that the cost of the marginal milk produced from imported feeds was greater than the milk price received in systems utilising $>500 \mathrm{~kg} \mathrm{DM} / \mathrm{cow}$ purchased feeds. Recent results from farm systems experiments in Ireland (Ruelle et al., 2018) and New Zealand Roche J. R., unpublished data) concur; the cost of marginal milk produced from inexpensive purchased feeds was greater than a moderate to good milk price, despite very good marginal milk production responses to the purchased feed.

From a cow perspective, there is one further complication. If supplements are to be used profitably, they cannot be used to fill the feed deficit completely. In an assessment of farm system intensification, Macdonald et al. (2017) concluded that to improve profitability, farms using purchased supplements needed to achieve high marginal milk production responses and, therefore, feed allowance/cow per year (i.e. pasture plus supplement) needed to be $\sim 10 \%$ less than on farms not importing feed. This conclusion explains some of the discrepancy on optimal stocking rate from research undertaken in similar grazing systems in New Zealand and Ireland (Macdonald et al., 2008a; McCarthy et al., 2010); optimum stocking rate in Ireland, where feed was imported for early and late lactation cows, was defined as $\sim 10 \%$ greater than in New Zealand, where no feed was imported (Macdonald et al., 2011; Roche and Horan, 2013). This has implications for cow robustness; it means that grazing systems, irrespective of availability of purchased feed, require a cow robust to short-term feed shortages.

In summary, profitability in grazing systems is strongly associated with pasture utilisation/ha and low unit costs of production; low unit cost of production is strongly associated with the proportion of the cow's diet that is grazed pasture. Imported feeds support biological robustness, allowing BC gain in late lactation and facilitating the management of feed shortages. However, they can undermine profitability, at least in systems designed to require $>500 \mathrm{~kg}$ DM of imported feed/cow per year. Profitable use of supplementary feeds requires that the feed allowance/cow per year is less than in grazing systems not importing feeds (i.e. stocking rate must be higher). Therefore, an essential characteristic of the most suitable cow for a grazing system is robustness to periodic, small, feed deficits.

\section{Environmental sustainability}

In addition to the need for economic and biophysical robustness, a relatively recent requirement is the need to reduce the farm's negative impact on the environment (i.e. the farm's environmental footprint). The historical and cynical adage that 'you have to be in the black to be green', insinuating that you cannot be environmentally responsible unless you are profitable, has been replaced by public voice that farmers will not be allowed to operate unless they can prove that their environmental footprint is sustainable. From a grazing system perspective, the greatest risks to environmental sustainability and, therefore, business robustness are the contribution of nitrate $\left(\mathrm{NO}_{3}^{-}\right)$to ground water degradation and methane $\left(\mathrm{CH}_{4}\right)$ and nitrous oxide $\left(\mathrm{N}_{2} \mathrm{O}\right)$ to climate change. In environmental impact, $\mathrm{CH}_{4}$ can be considered as a net loss of energy, whereas $\mathrm{NO}_{3}^{-}$is, at farm level, manageable and, in some instances, recyclable, and can, actually, contribute to reducing inputs in the form of mineral fertilisers (Huebsch et al., 2013). 
Methane is a natural consequence of the ruminant's ability to digest fibre and corresponds to $5 \%$ to $10 \%$ of gross energy intake (Van Soest, 1982). The primary factor influencing $\mathrm{CH}_{4}$ yield is the cow's intake of digestible organic matter (Wims et al., 2010; Hammond, 2011), although the composition of the pasture must also be considered (Wims et al., 2010; Enriquez-Hidalgo et al., 2014; Williams et al., 2016). Nevertheless, there is considerable variation in, and reasonable heritability for, $\mathrm{CH}_{4}$ production ( $\mathrm{g} /$ day; heritability of 0.26 ) and $\mathrm{CH}_{4}$ intensity ( $\mathrm{g} / \mathrm{l}$ milk; heritability of 0.21 ); PinaresPatiño et al., 2013; Lassen and Løvendahl, 2016), supporting a possible genetic solution to reduce $\mathrm{CH}_{4}$ emissions. There is no evidence that there are differences in the expression of the trait in different environments (Robertson and Waghorn, 2002; Van Der Nagel et al., 2003). However, there are possible differences in the importance of the breeding goal because of differences in the contribution of livestock emissions to individual countries' national inventory. This $\mathrm{G} \times \mathrm{E}$ must be considered in future breeding objectives for the robust cow.

The nitrogen footprint of grazing systems is more complex. Ruminant production systems are particularly inefficient in their conversion of ingested nitrogen to exported product (Huebsch et al., 2013). A key contributor to this is dietary intake of nitrogen, with urinary nitrogen yield increasing exponentially with nitrogen intake above $400 \mathrm{~g} /$ day (i.e. CP of $\sim 17 \% \mathrm{DM}$ ) and $\sim 80 \%$ of nitrogen consumed above this threshold lost in urine (Kebreab et al., 2001). As fresh pasture tends to be very high in nitrogen throughout the year (Roche et al., 2009c), the potentially leachable nitrogen load in each urine patch is very high (Selbie et al., 2015; Roche et al., 2016a). It is further complicated by soil type (Hack-ten Broeke et al., 1996) and the timing of urinary $\mathrm{N}$ excretion (Selbie et al., 2015; Roche et al., 2016a), with free-draining soils and urine deposited in autumn, both risk factors for greater nitrogen loss to ground water.

Genetic selection options to reduce urinary nitrogen concentrations have been proposed as a possible strategy for building robustness into grazing systems from an environmental sustainability perspective, but identifying a measurable and informative phenotype is key to success. The use of milk urea nitrogen (MUN) has been proposed as a potential phenotype to select animals for low urinary nitrogen concentrations. There is a positive correlation between MUN and urinary nitrogen yield (Jonker et al., 1998; Kauffman and St-Pierre, 2001; Nousiainen et al., 2004) in housed cows fed mixed rations, which is consistent with our data from grazing dairy cows (Roche J. R., unpublished data).

It appears, therefore, that MUN could, potentially, be used as a phenotype to select bulls for lower urinary nitrogen excretion. From a genetics perspective, Miglior et al. (2007) reported that average daily heritability for MUN was moderately high (from 0.38 to 0.41 ), providing confidence of a genetic-level solution to the nitrogen footprint of grazing systems. In New Zealand, modelling indicates that reducing the national herd's average breeding value for MUN by
2.4 units could, if successful, reduce nitrogen leaching by $17 \%$, assuming the phenotypic MUN to urinary nitrogen relationship represents a genetic correlation (Mark Camara, personal communication).

From a $G \times E$ perspective, there is no evidence that the expression of the genotype is different in different environments. However, where nitrogen-loss limits are imposed (i.e. so called, $\mathrm{NO}_{3}^{-}$sensitive zones), profitability will be defined as margin $/ \mathrm{kg} \mathrm{NO}_{3}^{-}$leached (Roche et al., 2016a) rather than per cow or per ha. Therefore, breeding objectives for these environments require emphasis on this trait (or a correlated trait) to ensure that the breeding goal remains holistic.

In summary, although the expression of the genotype for environmental measurements does not appear to change with environment, the importance of environmental traits will vary with regional and national priorities. Therefore, there is likely to be differences in the definition of the breeding goal in different environments and, as such, the $\mathrm{G} \times \mathrm{E}$ interaction needs to be accounted for in the 'environment' breeding objective.

\section{Summary}

There is little evidence of a large $G \times E$ for individual cow traits; but, there is clear evidence that differences exist in the importance of key animal-level traits in different farming systems (e.g. fertility in grazing systems, the economics of imported supplements, the importance of cow urinary nitrogen output or $\mathrm{CH}_{4}$ yield). Differences in the definition of the breeding goal for different environments, therefore, constitute a $\mathrm{G} \times \mathrm{E}$ interaction that has consequences for the type of cow required for different systems to ensure they are robust to the periodic challenges of milk price and the environment in which they operate.

\section{Genotype $\times$ environment interactions - do we need to choose different cows for different systems?}

Genotype by environment interactions are defined as 'the phenomenon that performances of different genotypes are not equally affected by different environments' (Falconer, 1952). Two types of $G \times E$ interactions exist: (1) re-scaling, which is a change in the relative magnitude of the difference between genotypes (e.g. individual animals, strains and breeds) in different environments; and (2) re-ranking, where the ranking of genotypes differs by environment. The greater the genetic diversity between genotypes and/or the larger the differences between environments, the greater the likelihood of $G \times E$ interactions existing (Falconer, 1989). The phenotype of interest also impacts the extent of genetic variability; of particular note, in the absence of re-ranking for any trait in a breeding objective, re-scaling in the breed goal traits can result in a re-ranking for the index (Namkoong, 1985).

Quantification of the extent of $G \times E$ interactions is important, since it affects genetic gain. If only a scaling effect exists, then only the magnitude of genetic gain differs 
from expectation: the same genotypes rank highest irrespective of environment. If, however, re-ranking occurs and is not considered, genetic gain will be reduced and could be unfavourable if the genetic correlation between the traits in the two environments is negative.

Genotype $\times$ environment interactions can be due to:

1) true differences in the expression of a genotype in different environments;

2) differences in the definition of the trait or the statistical model(s) applied in the environments compared; or

3) differences due to the relative emphasis on traits within an overall breeding objective.

\section{Differences in the expression of a genotype in different environments}

Genotype $\times$ environment interactions in dairy cows in grazing systems have been the subject of much debate and experimentation for more than 50 years (Roche et al., 2017a). For example, McMeekan (1960) reported that New Zealand farmers believed that the stocking rate research undertaken at Ruakura in the 1950s was not applicable commercially because the cows used in the research were genetically superior to the average commercial cow, since they had been bred using artificial insemination with genetically superior sires. This criticism was subsequently proven to have little validity, with the higher genetic merit cows proving their superiority, irrespective of the stocking rates implemented (Carter, 1964). The difference between the systems compared, however, was not great, reflecting only a difference in feed allowance/cow (i.e. small divergence in environment); so, the lack of an interaction is not surprising.

Until the 1990s, the accepted paradigm, globally, was that environment did not re-scale the relative expression of dairy cow genetic merit, at least not for production-related traits. However, production systems evolved to be increasingly diverse during the 1970s and 1980s (Roche et al., 2017a), with increased availability of grains and co-products from the human food, textile and cosmetic industries. In many systems, cows were offered more than grazed and conserved pasture to increase milk production/cow (Stockdale, 2000; Bargo et al., 2003). This increased the likelihood of $\mathrm{G} \times \mathrm{E}$ interactions and, especially, if germplasm was transferred between countries. Nevertheless, several experiments indicated no $\mathrm{G} \times \mathrm{E}$ interaction for milk production. For example, the Canadian-New Zealand GXE study (CANZ) used 20 Canadian and $20 \mathrm{New}$ Zealand Holstein-Friesian bulls as Al sires for cows in 20 New Zealand and 10 Canadian herds in a $2 \times 2$ factorial arrangement (Peterson, 1988). Holmes (1995) reported that there was no interaction between the origin of the sires and the daughter's environment. There was, however, a significant interaction between individual sires within strain and the daughters' environment; as a result, the correlations between the sire estimated breeding values in the two countries were approximately half the expected values. Nevertheless, there was no evidence that the correlation was negative. These results were supported subsequently by controlled experiments in research herds in Ireland (Kennedy et al., 2002; Horan et al., 2005b) and New Zealand (Roche et al., 2006a; Macdonald et al., 2008b), wherein intensity of genetic selection for milk yield influenced the size of the milk production response to purchased feeds. In all of these studies, cows of North American origin genetically selected almost exclusively for milk production in a non-grazing system produced significantly more milk/kg concentrate offered than cows of New Zealand origin selected for a balance of production and functional traits within grazing production systems. Results from an experimental study in Australia (Fulkerson et al., 2008) supported these findings. Fulkerson et al. (2008) reported that cows did not express their genetic potential for milk production unless they were offered $\geqslant 800 \mathrm{~kg} \mathrm{DM}$ of concentrates. Below this level of supplementation, the association between cow genetic merit and milk production was less than predicted; however, above this level of supplementation, the cows did not exceed their predicted difference for milk production. These latest experiments indicated the existence of a $\mathrm{G} \times \mathrm{E}$ interaction, but that the effect on milk production was predominantly scaling, at least at the macro-level, although some re-ranking of individual sires did occur. Therefore, if only milk production is considered, differences in the expression of genotypes did exist, but the genotypes did not substantially re-rank between the production systems evaluated.

Breed comparisons during this period also supported the existence of a $\mathrm{G} \times \mathrm{E}$ interaction, but it was limited to a rescaling effect; breeds selected in an environment with more feed available produced more milk, subsequently, when in an environment with greater access to feed. For example, the greater milk production drive of the Holstein-Friesian and the associated greater 'hunger' (Roche et al., 2006b) resulted in lower post-grazing residuals (L'Huillier et al., 1988) compared with Jersey cows. This effect reduced pasture production/ha in a high stocking rate environment through overgrazing during summer and autumn and this negatively affected the profitability/ha of the Holstein-Friesian, when compared with Jersey cows under the same conditions (Spaans et al., 2018). However, under a lower stocking rate, when feed allowance per cow was greater, those same breed attributes resulted in greater milk production/cow in the Holstein-Friesian and an increase in profitability/ha relative to the Jersey.

In summary, comparing both across and within breeds, there is considerable evidence of a $\mathrm{G} \times \mathrm{E}$ interaction. Genotypes selected within dairy systems that have greater access to imported feed produce more milk when offered additional feed or when compared with genotypes selected from systems that import less feed. However, when ranking is based on milk production, this $\mathrm{G} \times \mathrm{E}$ interaction is a scaling effect, with little evidence of large-scale genetic reranking.

Differences in the definition of the trait or the statistical model applied in the environments compared

Genotype $x$ environment interactions in the form of rescaling or re-ranking, as well as being a result of biological 
differences in the expression of the variome (i.e. the whole set of genetic variations in a species), through phenotypic differences in contrasting production systems, can also be, simply, an artefact of differences in the definition of the trait or the underlying statistical modelling or data edits/collection mechanism in the contrasting environments (Berry, 2015 and 2018). Although one may believe that testing for the presence of $G \times E$ in a well-defined trait, like lactation protein yield, for example, is unlikely to suffer from "statistical $G \times E$ ", this may not, necessarily, be true. For example, most countries evaluate 305-day equivalent milk yield; New Zealand, however, bases its dairy cow genetic evaluations on 270-day yield, and, thus, probably contribute a re-scaling $\mathrm{G} \times \mathrm{E}$ when compared with other countries. Moreover, many countries (e.g. the United States) present their 305-day yield genetic evaluation on the scale of a mature equivalent, whereas others (e.g. Ireland) present the data on the scale of a first lactation animal, with others (e.g. the Netherlands) using a hybrid of the two. Furthermore, many countries now use test-day models in their genetic evaluation of milk production that facilitate the modelling of different lactation profiles for different animals; some countries, however, (e.g. the United States, Ireland) use repeatability models. Hence, even for something as ubiquitous in genetic selection indices as protein yield, which appears to be a well-defined trait, $G \times E$ can be detected, and some of this is attributable, simply, to the underlying mathematics of how the trait is defined and modelled.

The phenomenon is generally exacerbated for more complex traits such as fertility. Different countries use a plethora of different definitions and statistical models, or editing criteria, in defining reproductive performance. Ireland and New Zealand, both predominated by seasonal-calving, grazing production systems, use calving interval and calved in the first 42 days of the calving season, respectively, as the goal traits in their breeding objectives. Even within Ireland, alone, the genetic correlation between these two traits for the same animals in the same lactation is, on average, 0.45 (Berry et al., 2012). Therefore, when interpreting any documented $\mathrm{G} \times \mathrm{E}$ for a given trait across contrasting production systems, and especially across countries, the likely contribution of the mathematical and statistical properties of the comparison must be considered.

\section{Differences in the definition of the breeding goal (i.e. cow type by production system interactions)}

Because there was no large-scale re-ranking of genotypes across production systems when milk production was the primary trait of interest, Holstein-Friesian germplasm from farm systems that did not involve grazing or seasonal calving were increasingly used through the 1980s and 1990s because of their superior milk production ability (Harris and Kolver, 2001). In the 1990s, farmers increasingly reported concerns that the 'modern' Holstein-Friesian cow had inferior fertility performance when compared with her predecessor. Much of those protestations 'fell on deaf ears' because it was largely regarded that breeding for or against fertility traits was not possible due to its low heritability (Berry et al., 2014). Numerous experiments were undertaken in New Zealand (Kolver et al., 2002; Roche et al., 2006a; Macdonald et al., 2008b), Australia (Fulkerson et al., 2001 and 2008), France (Bedere et al., 2015, 2016, 2017a and 2017b) and Ireland (Buckley et al., 2000; Kennedy et al., 2002; Horan et al., 2005a) to determine if different genetic strains performed differently under different feeding systems, in a holistic or overall economic sense. Although there was evidence that feeding regimen influenced the marginal milk production response to non-pasture feed and the ability of the dairy cow to exhibit her genetic potential, compared with her peers (Kennedy et al., 2002; Fulkerson et al., 2008), the greatest differences between the strains were in the extent of their negative energy balance in early lactation (Buckley et al., 2000; Roche et al., 2006a; McCarthy et al., 2007) and in their pregnancy rates in a seasonal calving system (Horan et al., 2005c; Macdonald et al., 2008b; Bedere et al., 2017a). In brief, the 6-week in-calf rate for North American-derived Holstein-Friesian cows was 15 percentage points lower than for New Zealand-derived Holstein-Friesian cows (Horan et al., 2005c; Macdonald et al., 2008b), and the North American-derived Holstein-Friesian cows were less likely to survive to successive lactations (Harris and Kolver, 2001). These differences were irrespective of feeding regime, thus indicating no $\mathrm{G} \times \mathrm{E}$ interaction.

As evidence accumulated in seasonal-calving grazing systems of the inferior reproductive performance and survival of Holstein-Friesian strains selected heavily for milk production, breeding objectives evolved rapidly. In 2001, the Economic Breeding Index (EBI; Berry et al., 2007) was introduced in Ireland and included the two fitness traits of calving interval and survival, in addition to the milk yield traits. Similarly, fertility was included in the New Zealand national breeding goal in 2001. By 2017, the EBI included 18 traits encompassed within seven sub-indices: (1) milk production; (2) fertility and survival; (3) calving performance; (4) maintenance; (5) beef performance; (6) health; and (7) management (Figure 4). From the analysis of 1053 high-reliability Holsteins sires, Berry (2018) reported a correlation between the Net Merit Index (from the United States) and the EBI (from Ireland) of 0.66 , suggesting considerable reranking of sires on overall profit when comparing breeding objectives designed for high input confinement production systems against breeding objectives designed for grazing production systems. The effects of changing the Irish dairy cow breeding objective (i.e. EBI) on genetic trends for production of milk fat and protein and fertility are presented in Figure 5. Recognition of the success of this multi-trait approach in designing the ideal cow for seasonal calving and grazing systems has led to the development of the US Grazing Merit Index (GM\$; Gay et al., 2014) and the UK Seasonal Calving Index in 2014, with both indices putting increased emphasis on functional traits associated with grazing and the need to achieve pregnancy within $\sim 80$ days of calving. 


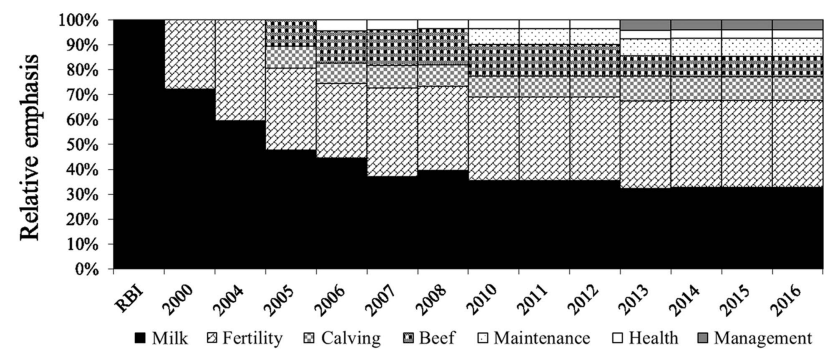

Figure 4 The evolution of the Economic Breeding Index in cattle, a multi-trait breeding objective in Ireland that includes traits other than production that are important to profitability. $\mathrm{RBI}=$ relative breeding index, the pre-cursor of the economic breeding index focussed breeding efforts solely on production.

\section{Summary}

As only $\sim 10 \%$ of the world's milk production originates from grazing systems, most ruminant livestock globally have not been directly selected for grazing systems. Until recently, most experimental results indicated little or no importance of $\mathrm{G} \times \mathrm{E}$ interactions on a trait by trait basis (Holmes, 1995); however, adoption of more diverse genotypes and/or production environments has increased the likelihood of such interactions, especially at the level of overall profitability (Falconer, 1952 and 1989). Strong evidence now exists to show that the animals genetically best suited to non-grazing systems are not best suited to grazing systems, predominantly because of their compromised reproductive performance, which is independent of feeding system (Horan et al., 2005c; Macdonald et al., 2008b; Delaby et al., 2010; Roche et al., 2017a).

\section{Cows for courses: choosing the right cow for grazing systems?}

Whether a separate breeding programme for grazing systems is required is a function of: (i) the intensity of selection for the breeding goal, (ii) the maximum genetic correlation between the breeding objective in a grazing system and all breeding objectives in other populations from where semen can be imported and (iii) the cost of implementing a separate breeding programme tailored for grazing systems.

The requirement for a separate breeding programme can be illustrated using an example of two dairy systems: a housed system, in which cows are offered a mixed ration, and an intensive grazing system, in which the primary source of feed is fresh pasture. For simplicity, the generation interval, genetic variance and accuracy of selection are assumed to be identical in both environments. The accuracy of an animal's estimated breeding value in the grazing system, having been evaluated in the housed system, is the accuracy in the housed system multiplied by the genetic correlation between the systems. The number of sires that must be evaluated in the grazing system to achieve similar genetic progress to using sires evaluated in the housed production system, therefore, declines as the genetic correlation between the breeding objectives in both production systems

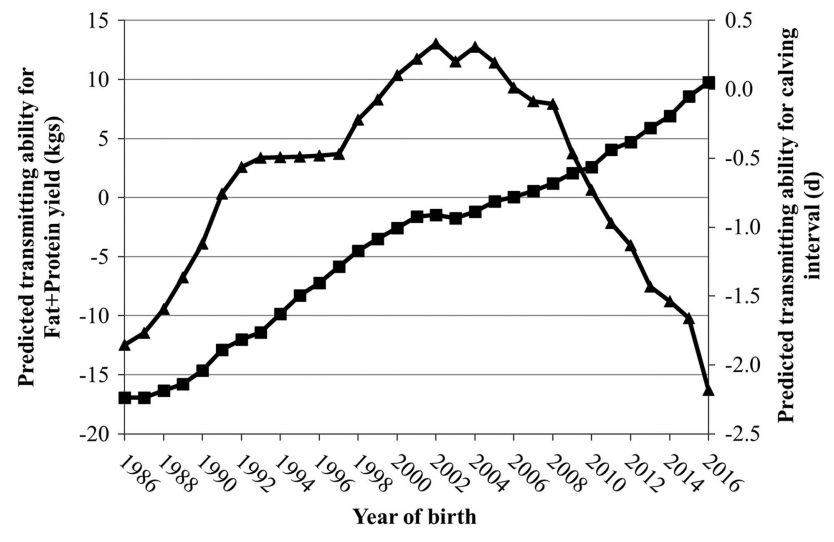

Figure 5 The effect of the Economic Breeding Index introduction in Ireland in 2001 on genetic trends for milk fat and protein production ( $\square$ ) and calving interval in cattle, as a measure of fertility $(\boldsymbol{\Delta})$. Despite the reduced weighting on milk production and increased weighting on fertility, the genetic trends for increased milk production did not diminish.

weaken. For example, when the correlation between breeding objectives across the systems is $0.6,0.7,0.8$ or 0.9 , the number of sires that must be evaluated in the grazing system to achieve the same genetic progress as importing semen from the breeding programme with 100 sires evaluated under housed production systems is $28,37,51$ and 71 , respectively. This is because the greater the dissimilarity between breeding objectives (i.e. weaker genetic correlations), the less applicable the breeding objective for the housed production system is for selecting elite animals under grazing production; thus, the greater the difference between farming systems, the fewer sires that must be tested under grazing production systems to achieve the same gains. Therefore, the justification of a separate breeding programme is dependent on the extent of $G \times E$ with other breeding programmes and the actual size and structure (i.e. ability to achieve high accuracy of selection) of those breeding programmes.

Not considered here, however, is the long-term security of having a grazing-specific breeding programme and the risks associated with relying on an external breeding programme. Although genomic selection will reduce the benefit (and burden) of progeny testing in the future, large training population sizes used to estimate genetic marker effects for inclusion in genomic predictions are still required and the estimates of genetic merit in these reference animals should still be based on information generated from grazing production systems (and breeds).

\section{Characteristics of a grazing cow}

Systems based on greater use of 'service offerings' from nature (i.e. low supplementary feed input systems, organic systems) must cope with more variability in feed availability and quality and climate. Such systems, therefore, require animals that are robust, autonomous and 'easy care', and capable of high levels of performance from a predominantly grazed pasture diet. As the genetic correlation between 
breeding objectives in grazing systems and systems where cows are housed and offered mixed rations tend to be weak (i.e. correlation of 0.66 between the US and Irish dairy cow breeding objectives, as described earlier) and the overwhelming evidence from experiments undertaken over the last two decades is that cows selected from within housed systems are not appropriate for grazing systems, there is a good justification for selecting a 'grazing-appropriate' cow.

Several countries have focussed their breeding objectives on the cow characteristics important for profitability in a grazing system (e.g. New Zealand, Ireland, UK, United States and Australia). Grazing systems require a cow with good grazing characteristics and a propensity for high pasture DMI, that has good fertility and is 'easy care' and docile, that can walk long distances, that is resistant to some of the diseases of grazing systems (e.g. hypomagnesaemia, foamy bloat) and that is robust to fluctuations in feed quality and quantity (Berry, 2015; Friggens et al., 2017; Delaby et al., 2018). These traits are fundamental for grazing systems to be successful and robust from 1 year to the next, as:

- cow demand is set strategically (i.e. stocking rate) and is not easily changed annually, despite variability in pasture supply;

- the cow must be able to walk reasonable distances to and from their feed source and harvest large quantities quickly;

- the cow must establish and maintain pregnancy within $\sim 80$ days of calving to maintain the seasonal calving pattern and the alignment between supply and demand; and

- must not require an inordinate amount of individual attention (i.e. 'easy care'), as, in general, there are two to three times more cows/person in an intensively managed grazing system compared with a housed system.

In addition to these functional traits, traits associated with the environmental footprint of the cow must also be considered. A future requirement of robust systems will be that they produce less $\mathrm{CH}_{4}$ and will have a lower nitrogen footprint (i.e. lower $\mathrm{NO}_{3}^{-}$leaching and $\mathrm{N}_{2} \mathrm{O}$ emissions). Further research efforts need to investigate a genetic solution for these problems as well as the management mitigation strategies being explored.

\section{Robust grazing cows: adapting to changes in feed supply and quality}

Economically robust grazing systems are defined by the high levels of pasture utilisation and a reduced exposure to external price fluctuations (Ramsbottom et al., 2015). Pasture utilisation is primarily determined by stocking rate (Macdonald et al., 2008a; McCarthy et al., 2016), with high stocking rates resulting in a high proportion of the pasture being directly harvested by the cow and low stocking rates resulting in either lower pasture utilisation or a greater proportion of pasture utilised via silage or hay. High stocking rates increase the likelihood of short-term feed deficits, particularly in the change between winter and spring and between autumn and winter. The cow for this system, therefore, must be able to absorb short-term feed deficits and be able to preserve $\mathrm{BC}$, through reducing milk production, and respond to re-feeding when feed supply resumes. This could be achieved by selecting for cows that are able to transfer mammary secretory cells from an active state to a 'quiescent' state, from which they can return to an active state when feeding resumes.

\section{Robust grazing cows: fertility}

As robust grazing systems are dependent on high pasture utilisation, they are designed so that the herd's demand for feed is matched as closely as possible with the pasture growth profile (Roche et al., 2017b). This requires all cows to calve over a short period ( $\sim 10$ weeks) and, by necessity, become pregnant in an equally short period and within $\sim 80$ days of calving. Achieving this requires the quick resolution of a range of physiological, endocrine and tissue re-modelling processes during a particularly nutrient demanding and both a physiologically and immunologically challenging period.

\section{Robust grazing cows: walking, pasture harvesting and the efficiency of grazing}

Grazing dairy cows are required to walk long distances daily and harvest their feed in a very competitive environment. In fact, cows in grazing systems will spend up to $10 \mathrm{~h}$ grazing each day (Linnane et al., 2004; Sheahan et al., 2011), whereas those indoors on mixed rations rarely need to eat for more than $5 \mathrm{~h}$ (Thorne et al., 2003). Genotypes have been reported to graze differently. For example, animals selected for high feed conversion efficiency spend less time grazing $/ \mathrm{kg}$ DMI (Gregorini et al., 2015) and animals selected exclusively for milk production exhibit less of a reduction in their time spent grazing when offered concentrate feeds than cows also selected for functional traits (i.e. $\mathrm{G} \times \mathrm{E}$ interaction; Linnane et al., 2004). Similarly, Thorne et al. (2003) reported that some genotypes of cows selected exclusively for milk production were more aggressive grazers, probably indicative of a greater hunger state, a neuroendocrine basis for which was reported by Roche et al. (2007). In summary, an ability to graze efficiently and walk long distances are necessary characteristics for efficient grazing dairy cows, which may not be as necessary for cows consuming mixed rations.

\section{Conclusions}

A $G \times E$ interaction is defined as the phenomenon that performances of different genotypes are not equally affected by different environments. Although there are instances in which the expression of a genotype differs in different environments, the greatest $G \times E$ interaction is due to different breeding objectives in different production systems and, as a result, the suitability of different cows for different production systems. Successful grazing systems require cows capable of achieving large intakes of forage so that they can achieve their nutritional requirements almost entirely from grazed pastures, with 
limited inputs of conserved forage and imported feed supplements. They must be able to produce reasonable quantities of milk (i.e. 5500 to $7500 \mathrm{~kg} ; 350$ to $500 \mathrm{~kg}$ milk fat and protein), primarily from grazed pasture, walk long distances and become pregnant within $\sim 80$ days of calving. Such autonomous grazing animals must also be able to maintain adequate $B C$ to avoid ill health within a periodic restricted feed environment (Delaby et al., 2009; Piccand et al., 2011). In addition, in the context of 'sustainable intensification', grazing cows must produce less $\mathrm{CH}_{4}$ and must excrete a lower concentration and amount of nitrogen in urine. Many of these requirements are different to the priorities in housed dairy systems and this $\mathrm{G} \times \mathrm{E}$ needs to be considered in breeding objectives as researchers identify traits for selection or suitably precise proxies, so that farmers can choose cows to suit their production system. Each country must evaluate the factors most influencing the robustness traits we've discussed, place a weighting on their importance to system or cow robustness and develop an appropriate breeding objective to ensure the cow of the future underpins a dairy system robust to climatic and financial challenges.

\section{Acknowledgements}

J. R. Roche acknowledges New Zealand dairy farmers, through DairyNZ Incorporated (RD1405), and the New Zealand Government, through the Ministry of Business, Innovation, and Employment (DRCX1302) for their financial contribution towards compiling this manuscript.

\section{Declaration of interest}

None.

\section{Ethics statement \\ None.}

\section{Software and data repository resources None.}

\section{References}

Bargo F, Muller LD, Kolver ES and Delahoy JE 2003. Invited review: production and digestion of supplemented dairy cows on pasture. Journal of Dairy Science 86, 1-42.

Bedere N, Delaby L, Ducrocq V, Leurent-Colette S and Disenhaus C 2015 Resumption of luteal activity in first lactation cows is mainly affected by genetic characteristics. 66th Annual Meeting of the European Federation of Animal Science (EAAP) 21, 276.

Bedere N, Delaby L, Leurent-Colette $S$ and Disenhaus C 2016. The cow for the system: limiting milk yield and body condition loss to ensure reproduction on time TT. 67th Annual Meeting of the European Federation of Animal Science (EAAP) 22, 630.

Bedere N, Disenhaus C, Ducrocq V, Leurent-Colette S and Delaby L 2017a. Ability of dairy cows to ensure pregnancy according to breed and genetic merit for production traits under contrasted pasture-based systems. Journal of Dairy Science 100, 2812-2827.

Bedere N, Disenhaus C, Ducrocq V, Leurent-Colette S and Delaby L 2017b. Ability of dairy cows to be inseminated according to breed and genetic merit for production traits under contrasting pasture-based feeding systems. Animal 11, 826-835.

Berry DP 2015. Breeding the dairy cow of the future: what do we need? Animal Production Science 55, 823-837.
Berry DP 2018. Breeding a better cow - will she be adaptable? Journal of Dairy Science 101, 3665-3685.

Berry DP, Kearney JF, Twomey K and Evans RD 2012. Genetics of reproductive performance in seasonal calving dairy cattle production systems. Irish Journal of Agricultural and Food Research 52, 1-16.

Berry DP, Shalloo L, Cromie AR, Veerkamp RF, Dillon P, Amer PR, Kearney JF, Evans RD and Wickham B 2007. The economic breeding index: a generation on. Technical report to the Irish Cattle Breeding Federation, pp. 1-50. Retrieved on 15 February 2017 from http://www.icbf.com/publications/files/economic breeding_index.pdf.

Berry DP, Wall E and Pryce JE 2014. Genetics and genomics of reproductive performance in dairy and beef cattle. Animal 8, 105-121.

Bommarco R, Kleijn D and Potts SG 2013. Ecological intensification: harnessing ecosystem services for food security. Trends in Ecology and Evolution 28, 230-238. Buckley F, Dillon P, Rath M and Veerkamp RF 2000. The relationship between genetic merit for yield and live weight, condition score, and energy balance of spring calving holstein friesian dairy cows on grass based systems of milk production. Journal of Dairy Science 83, 1878-1886.

Carter AH 1964. How important is dairy merit? Proceedings of the Ruakura Farmers' Conference 15, 188-203.

DairyCo 2013. Managing costs - key findings of the Milkbench + dairy benchmarking programme regarding the efficiency of dairy production in Britain. Animal \& Horticulture Development Board, Warwickshire, UK.

Delaby L, Buckley F, McHugh N and Blanc F 2018. Resilient animals for grass based production systems. In Proceedings of the European Grassland Federation, p. in press. Cork, Ireland.

Delaby L, Faverdin P, Michel G, Disenhaus C and Peyraud JL 2009. Effect of different feeding strategies on lactation performance of Holstein and Normande dairy cows. Animal 3, 891-905.

Delaby L, Horan B, O'Donovan M, Gallard Y and Peyraud JL 2010. Are high genetic merit dairy cows compatible with low input grazing systems? In: Grassland in a changing world (p. 928-930). Grassland Science in Europe, 15. In Paper Presented at the 23rd General Meeting of the European Grassland Federation, 29 August to 2 September 2010, Zürich, pp. 928-930.

Dillon P, Roche JR, Shalloo L and Horan B 2005. Optimising financial return from grazing in temperate pastures. In Utilisation of grazed grass in temperate animal systems. Proceedings of a satellite workshop of the XXth International Grassland Congress, July 2005, Cork, Ireland, pp. 131-147.

Enriquez-Hidalgo D, Gilliland T, Deighton MH, O'Donovan M and Hennessy D 2014. Milk production and enteric methane emissions by dairy cows grazing fertilized perennial ryegrass pasture with or without inclusion of white clover. Journal of Dairy Science 97, 1400-1412.

Falconer DS 1952. The problem of environment and selection. The American Naturalist 86, 293-298.

Falconer DS 1989. Introduction to quantitative genetics. John Wileys and Sons, Essex, UK.

Friggens NC, Blanc F, Berry DP and Puillet $L$ 2017. Review: deciphering animal robustness. A synthesis to facilitate its use in livestock breeding and management. Animal 11, 2237-2251.

Fulkerson WJ, Davison TM, Garcia SC, Hough G, Goddard ME, Dobos R and Blockey M 2008. Holstein-Friesian dairy cows under a predominantly grazing system: interaction between genotype and environment. Journal of Dairy Science $91,826-839$.

Fulkerson W, Wilkins J, Dobos RC, Hough GM, Goddard ME and Davison T 2001. Reproductive performance in Holstein-Friesian cows in relation to genetic merit and level of feeding when grazing pasture. Animal Science 73, 397-406.

Gay KD, Widmar NJO, Nennich TD, Schinckel AP, Cole JB and Schutz MM 2014. Development of a lifetime merit-based selection index for US dairy grazing systems. Journal of Dairy Science 97, 4568-4578.

Gregorini P, Waghorn GC, Kuhn-Sherlock B, Romera AJ and Macdonald KA 2015. Short communication: grazing pattern of dairy cows that were selected for divergent residual feed intake as calves. Journal of Dairy Science 98, 6486-6491. Hack-ten Broeke MJD, De Groot WJM and Dijkstra JP 1996. Impact of excreted nitrogen by grazing cattle on nitrate leaching. Soil Use and Management 12, 190-198.

Hammond KJ 2011. Methane emissions from ruminants fed white clover and perennial ryegrass forages. Doctorat science animale, Massey University, Nouvelle Zélande. p. 257. 
Harris BL and Kolver ES 2001. Review of holsteinization on intensive pastoral dairy farming in New Zealand. Journal of Dairy Science 84, E56-E61.

Hochman Z, Carberry PS, Robertson MJ, Gaydon DS, Bell LW and McIntosh PC 2013. Prospects for ecological intensification of Australian agriculture. European Journal of Agronomy 44, 109-123.

Holmes CW 1995. Genotype X environment interactions in dairy cattle: a New Zealand perspective. In BSAS Occasional Publication Breeding and Feeding the High Genetic Merit Dairy Cow (ed. by TLJ Lawrence, FJ Gordon and A Carson), pp. 51-66. British Society of Animal Science, Midlothian, UK. Horan B, Dillon P, Berry DP, O'Connor P and Rath M 2005a. The effect of strain of Holstein-Friesian, feeding system and parity on lactation curves characteristics of spring-calving dairy cows. Livestock Production Science 95, 231-241.

Horan B, Dillon P, Faverdin P, Delaby L, Buckley F and Rath M 2005b. The interaction of strain of Holstein-Friesian cows and pasture-based feed systems on milk yield, body weight, and body condition score. Journal of Dairy Science 88, 1231-43.

Horan B, Mee JF, O'Connor P, Rath M and Dillon P 2005c. The effect of strain of Holstein-Friesian cow and feeding system on postpartum ovarian function, animal production and conception rate to first service. Theriogenology 63 , 950-971.

Huebsch M, Horan B, Blum P, Richards KG, Grant J and Fenton 0 2013. Impact of agronomic practices of an intensive dairy farm on nitrogen concentrations in a karst aquifer in Ireland. Agriculture, Ecosystems and Environment 179, 187-199.

Jonker JS, Kohn RA and Erdman RA 1998. Using milk urea nitrogen to predict nitrogen excretion and utilization efficiency in lactating dairy cows. Journal of Dairy Science 81, 2681-2692.

Kauffman AJ and St-Pierre NR 2001. The relationship of milk urea nitrogen to urine nitrogen excretion in Holstein and Jersey cows. Journal of Dairy Science 84, 2284-2294.

Kebreab E, France J, Beever DE and Castillo AR 2001. Nitrogen pollution by dairy cows and its mitigation by dietary manipulation. Nutrient Cycling in Agroecosystems 60, 275-285.

Kennedy J, Dillon P, Faverdin P, Delaby L, Buckley F and Rath M 2002. The influence of cow genetic merit for milk production on response to level of concentrate supplementation in a grass-based system. Animal Science 75, 433-445.

Kolver ES, Roche JR, de Veth MJ, Thorne PL and Napper AR 2002. Total mixed ratios versus pasture diets. Evidence for a genotype $\mathrm{x}$ diet interaction in dairy cow performance. Proceedings of the New Zealand Society of Animal Production 62, 246-251.

L'Huillier PJ, Parr CR and Bryant AM 1988. Comparative performance and energy metabolism of Jerseys and Friesians in early-mid lactation. Proceedings of the New Zealand Society of Animal Production 48, 231-235.

Lassen J and Løvendahl P 2016. Heritability estimates for enteric methane emissions from Holstein cattle measured using noninvasive methods. Journal of Dairy Science 99, 1959-1967.

Linnane $\mathrm{M}$, Horan B, Connolly J, O'Connor P, Buckley F and Dillon P 2004. The effect of strain of Holstein-Friesian and feeding system on grazing behaviour, herbage intake and productivity in the first lactation. Animal Science 78, 169-178.

Macdonald KA, Beca D, Penno JW, Lancaster JAS and Roche JR 2011. Short communication: effect of stocking rate on the economics of pasture-based dairy farms. Journal of Dairy Science 94, 2581-2586.

Macdonald KA, Penno JW, Lancaster JAS, Bryant AM, Kidd JM and Roche JR 2017. Production and economic responses to intensification of pasture-based dairy production systems. Journal of Dairy Science 100, 6602-6619.

Macdonald KA, Penno JW, Lancaster JAS and Roche JR 2008a. Effect of stocking rate on pasture production, milk production, and reproduction of dairy cows in pasture-based systems. Journal of Dairy Science 91, 2151-2163.

Macdonald KA, Verkerk GA, Thorrold BS, Pryce JE, Penno JW, McNaughton LR, Burton L, Lancaster JAS, Williamson JH and Holmes CW 2008b. A comparison of three strains of Holstein-Friesian grazed on pasture and managed under different feed allowances. Journal of Dairy Science 91, 1693-1707.

McCarthy S, Berry DP, Dillon P, Rath M and Horan B 2007. Influence of HolsteinFriesian strain and feed system on body weight and body condition score lactation profiles. Journal of Dairy Science 90, 1859-1869.

McCarthy B, Delaby L, Pierce KM, Journot F and Horan B 2010. A meta-analysis of the impact of stocking rate on the productivity of pasture-based milk production systems. Advances in Animal Biosciences 1, 148.
McCarthy B, Delaby L, Pierce KM, McCarthy J, Fleming C, Brennan A and Horan B 2016. The multi-year cumulative effects of alternative stocking rate and grazing management practices on pasture productivity and utilization efficiency. Journal of Dairy Science 99, 3784-3797.

McMeekan C 1960. Grass to milk - a New Zealand philosophy. New Zealand Dairy Exporter, Wellington, New Zealand.

Miglior F, Sewalem A, Jamrozik J, Bohmanova J, Lefebvre DM and Moore RK 2007. Genetic analysis of milk urea nitrogen and lactose and their relationships with other production traits in Canadian Holstein cattle. Journal of Dairy Science 90, 2468-2479.

Namkoong G 1985. The influence of composite traits on genotype by environment relations. Theoretical and Applied Genetics 70, 315-317.

Nousiainen J, Shingfield KJ and Huhtanen P 2004. Evaluation of milk urea nitrogen as a diagnostic of protein feeding. Journal of Dairy Science 87, 386-398.

Peterson R 1988. Comparison of Canadian and New Zealand sires in New Zealand for production, weight and conformation traits (Research Bulletin No. 5. Livestock Improvement Corporation Ltd, New Zealand Dairy Board, Newstead, New Zealand.

Piccand V, Cutullic E, Schori F, Weilenmann S and Thomet P 2011. Which cow for pasture-based production systems? Production, reproduction and health. Recherche Agronomique Suisse 2, 252-257.

Pinares-Patiño CS, Hickey SM, Young E A, Dodds KG, MacLean S, Molano G, Sandoval E, Kjestrup H, Harland R, Hunt C, Pickering NK and McEwan JC 2013. Heritability estimates of methane emissions from sheep. Animal 7 (suppl. 2), 316-321.

Pretty JN 1997. The sustainable intensification of agriculture. Natural Resources Forum 21, 247-256.

Pretty J and Bharucha ZP 2014. Sustainable intensification in agricultural systems. Annals of Botany 114, 1571-1596.

Ramsbottom G, Horan B, Berry DP and Roche JR 2015. Factors associated with the financial performance of spring-calving, pasture-based dairy farms. Journal of Dairy Science 98, 3526-3540.

Robertson $\mathrm{U}$ and Waghorn GC 2002. Dairy industry perspectives on methane emissions and production from cattle fed pasture or total mixed rations in New Zealand. Proceedings of the New Zealand Society of Animal Production 62, 213218.

Roche JR 2007. Milk production responses to pre- and postcalving dry matter intake in grazing dairy cows. Livestock Science 110, 12-24.

Roche JR 2017. Nutrition manage of grazing dairy cattle. In Achieving sustainable production of milk volume 3: dairy herd management (ed. Webster J), pp. 251-272. Burleigh-Dodds Science Publishing, Cambridge, UK.

Roche JR, Berry DP, Bryant AM, Burke CR, Butler ST, Dillon PG, Donaghy DJ, Horan B, Macdonald KA and Macmillan KL 2017a. A 100-year review: a century of change in temperate grazing dairy systems. Journal of Dairy Science 100 , 10189-10233.

Roche JR, Berry DP and Kolver ES 2006a. Holstein-Friesian strain and feed effects on milk production, body weight, and body condition score profiles in grazing dairy cows. Journal of Dairy Science 89, 3532-3543.

Roche JR, Friggens NC, Kay JK, Fisher MW, Stafford KJ and Berry DP 2009a. Invited review: body condition score and its association with dairy cow productivity, health, and welfare. Journal of Dairy Science 92 , 5769-5801.

Roche JR and Horan B 2013. Resilient farming systems for an expanding Irish dairy industry. In Irish dairying - harvesting the potential (ed. D. Berry, S. Butler and P. Dillon), pp. 15-24. Teagasc, Animal \& Grassland Research and Innovation Centre, Moorepark, Co. Cork, Ireland; Fermoy, Co. Cork, Ireland.

Roche JR, Ledgard SF, Sprosen MS, Lindsey SB, Penno JW, Horan B and Macdonald KA 2016a. Increased stocking rate and associated strategic dry-off decision rules reduced the amount of nitrate-N leached under grazing. Journal of Dairy Science 99, 5916-5925.

Roche JR, Ledgard SF, Sprosen MS, Lindsey SB, Penno JW, Horan B and Macdonald KA 2016b. Increased stocking rate and associated strategic dry-off decision rules reduced the amount of nitrate-N leached under grazing. Journal of Dairy Science 99, 5916-5925.

Roche JR, Sheahan AJ, Chagas LM and Berry DP 2006b. Short communication: genetic selection for milk production increases plasma ghrelin in dairy cows. Journal of Dairy Science 89, 3471-3475. 
Roche JR, Sheahan AJ, Chagas LM and Berry DP 2007. Concentrate supplementation reduces postprandial plasma ghrelin in grazing dairy cows: a possible neuroendocrine basis for reduced pasture intake in supplemented cows. Journal of Dairy Science 90, 1354-1363.

Roche JR, Turner LR, Lee JM, Edmeades DC, Donaghy DJ, Macdonald KA, Penno JW and Berry DP 2009b. Weather, herbage quality and milk production in pastoral systems. 1. Temporal patterns and intra-relationships in weather variables. Animal Production Science 49, 192-199.

Roche JR, Turner LR, Lee JM, Edmeades DC, Donaghy DJ, Macdonald KA, Penno JW and Berry DP 2009c. Weather, herbage quality and milk production in pastoral systems. 2. Temporal patterns and intra-relationships in herbage quality and mineral concentration parameters. Animal Production Science 49, 200-210.

Roche JR, Washburn SP, Berry DP, Donaghy DJ and Horan B 2017b. Seasonal pasture-based dairy production systems. In Large dairy herd management (ed. D. Beede), pp. 99-114. American Dairy Science Association, , Champaign, IL, USA

Ruelle E, Delaby L, Wallace M and Shalloo L 2018. Using models to establish the financially optimum strategy for Irish dairy farms. Journal of Dairy Science 101, 614-623.

Selbie DR, Buckthought LE and Shepherd MA 2015. The challenge of the urine patch for managing nitrogen in grazed pasture systems. Advances in Agronomy 129, 229-292.

Sheahan AJ, Kolver ES and Roche JR 2011. Genetic strain and diet effects on grazing behavior, pasture intake, and milk production. Journal of Dairy Science 94, 3583-3591.

Spaans 0, Macdonald KA, Lancaster JAS, Bryant AM and Roche JR 2018. Dairy cow breed interacts with stocking rate in temperate pasture-based dairy production systems. Journal of Dairy Science 101, 4690-4702.
Stakelum G and Dillon P 1991. Influence of sward structure and digestibility on the intake and performance of lactating and growing cattle. In Management issues for the grassland farmer in the 1990s. Occasional Symposium of the British Grassland Society No. 25 (ed. C.S. Mayne), pp. 30-42. British Grassland Society, Hurley, UK.

Stockdale CR 2000. Levels of pasture substitution when concentrates are fed to grazing dairy cows in Northern Victoria. Australian Journal Experimental Agriculture 40, 913-921.

Thorne PL, Jago JG, Kolver ES and Roche JR 2003. Diet and genotype affect feeding behaviour of Holstein-Friesian dairy cows during late. Proceedings of the New Zealand Society of Animal Production, 124-127.

Tittonell P 2014. Ecological intensification of agriculture-sustainable by nature. Current Opinion in Environmental Sustainability 8, 53-61.

Van Der Nagel LS, Waghorn GC and Forgie VE 2003. Methane and carbon emissions from conventional pasture and grain-based total mixed rations for dairying. Proceedings of the New Zealand Society of Animal Production 63, 128-132.

Van Soest PJ 1982. Nutritional ecology of the ruminants, 2nd edition. Cornell University Press, Ithaca, NY, USA.

Williams SRO, Moate PJ, Deighton MH, Hannah MC, Wales WJ and Jacobs J 2016. Milk production and composition, and methane emissions from dairy cows fed lucerne hay with forage brassica or chicory. Animal Production Science $56,304-311$.

Wims CM, Deighton MH, Lewis E, O'Loughlin B, Delaby L, Boland TM and O'Donovan M 2010. Effect of pregrazing herbage mass on methane production, dry matter intake, and milk production of grazing dairy cows during the mid-season period. Journal of Dairy Science 93 4976-4985. 